\title{
Pendekatan Kontekstual Dalam Tugas Misi Dan Komunikasi Injil Pasca Pandemi Covid-19
}

\author{
Yakob Tomatala \\ Sekolah Tinggi Teologi Jaffray Jakarta \\ E-mail: tomatala.yakob@gmail.com
}

\begin{abstract}
God reveals Himself in contextual ways. In revealing Himself, He sets forth to do His will and through His will, God materializes His word. Furthermore, God's sovereign will is revealed in contextual ways in terms of today's community life in regards to the history of every human civilation. God's contextual self disclosure is not just an instrument that is used to display the essence of God, but it is also a method to comprehend His substance. In relation to God's self disclosure, the contextualized self disclosure of God provides a basis for implementing His mission through bringing and communicating the Gospel to every community context. This concept is thoroughly explained within the discourse about "The contextual approach in doing missions and communicating the Gospel in Post Covid-19 Pandemic era". This research underlies several important issues. These issues includes : First, Contextual Approach in Doing Missions; Second, Contextual Approach in Communicating the Gospel in Post Covid-19 Pandemic era. Hopefully through this discourse there is a broad overview about implementing the Great Commission of Christ Jesus in a contextual way in today's world specifically in the Post Covid-19 period.
\end{abstract}

Keyword: Contextual Approach, Missionary Movement, Communicating the Gospel

\begin{abstract}
Abstrak
Penyataan TUHAN Allah dalam sejarah adalah kontektual. Penyataan Allah yang kontekstual melibatkan kehendak-Nya yang berdaulat sebagai landasan dari semua tindakan-Nya. Pada sisi lain, penyataan TUHAN yang berdaulat dinyatakan-Nya secara kontektual pada konteks kehidupan kekinian dalam sejarah setiap masyarakat. Penyataan TUHAN yang kontekstual bukan saja sebagai cara penyataan diri-Nya, tetapi sekaligus adalah metode untuk memahami Dia. Dalam kaitan ini, penyataan TUHAN yang kontekstual menyiapkan landasan bagi pelaksanaan misi-Nya dengan menghadirkan dan mengkomunikasikan Injil pada setiap konteks kehidupan masyarakat. Gagasan ini dituangkan melalui diskursus tentang "Pendekatan kontekstual dalam tugas misi dan komunikasi Injil Pasca Pandemi Covid-19" yang mengetengahkan beberapa pokok penting. Pokok-pokok dimaksud antara lain adalah: Pertama, Pendekatan Kontektual dalam Gerakan Misi; Kedua, Pendekatan Kontekstual dalam Komunikasi Injil pada Konteks Pasca Pandemi Covid-19. Diharapkan agar diskursus ini memberikan gambaran mengenai pelaksanaan Amanat Agung Yesus Kristus secara kontekstual dalam kondisi dunia kekinian khususnya pada konteks pasca Pandemi Covid-19.
\end{abstract}

Kata kunci: Pendekatan Kontekstual, Gerakan Misi, Komunikasi Injil

\section{Pendahuluan}

Gagasan kontekstual dan kontektualisasi dalam berteologi telah dikembangkan di Indonesia, sejak paruhan tengah dan akhir Abad XX. ${ }^{1}$ Tema tentang konteksual dapat

\footnotetext{
${ }^{1}$ Eka Dharmaputra, Konteks Berteologi Di Indonesia (Jakarta: BPK Gunung Mulia, 1991).
} 
ditemukan dalam tulisan Eka Dharmaputra (1991) dan kontekstualisasi yaitu proses berteologi dalam konteks di kalangan Kristen dapat dilihat dari literatur yang beredar pada awal tahun 1990-an. ${ }^{2}$ Contoh gagasan kontekstualisasi dalam khasanah keilmuan Islam, dikembangkan oleh beberapa tokoh seperti Budi Rahmat Halim (2014). ${ }^{3}$ Pada dasarnya, misi dan pendekatan kontekstual serta kontekstualisasi dalam tugas misi ${ }^{4}$ sudah diadvokasi di kalangan Kristen untuk waktu yang cukup lama, ${ }^{5}$ baik di dunia internasional mau pun di Indonesia. Woga menggukapkan penggunaan istilah misi dalam khasana teologi Gereja pada masa Raymond Lull (1232-1236); dan di Konsili Vienna (1311), dsb. ${ }^{6}$

Pada sisi lain, kontekstual dan kontekstualisasi dapat dijelaskan sebagai cara TUHAN yang menyatakan diri untuk dipahami. Penyataan TUHAN (self-disclosure) dan pernyataanNya (self-revelation) dilaksanakan-Nya atas kehendak-Nya yang berdaulat, yang terwujud secara kontekstual dalam setiap konteks. Kebenaran ini menegaskan bahwa segala sesuatu adalah bersumber dari TUHAN Allah yang adalah sumber azali dari semua substansi baik materi dan non-materi (Roma 11:36). TUHAN Allah yang berdaulat dalam penyataan diri dan pernyataan kehendak-Nya yang kekal selalu bersifat kontekstual, yang menyentuh konteks kehidupan manusia secara menyeluruh. Penyataan dan pernyataan Allah yang kontekstual ini menjelaskan bahwa orientasi pendekatan-Nya kepada setiap orang dan kelompok masyarakat terjadi dalam "proses kontekstualisasi" di dalam ruang dan waktu yang historis. Proses kontekstualisasi menjelaskan bahwa tatkala penyataan dan pernyataan TUHAN diwujudkan melalui misi-Nya, Ia selalu menggunakan bentuk, arti dan fungsi dari elemen budaya terpilih serta dikenal ke dalam dan di dalam konteks kehidupan setiap masyarakat. Kisah Anak Perdamaian oleh Don Richardson di kalangan suku sawi, Papua, adalah contoh bagaimana TUHAN Allah menggunakan elemen budaya terpilih dalam pelaksanaan misi-Nya dengan bentuk, arti serta fungsi yang redemptive analogy. ${ }^{7}$ Tujuan dari penyataan dan pernyataan TUHAN yang kontekstual ini adalah untuk menghadirkan diri-Nya dan membuat diri-Nya dipahami melalui melalui misi-Nya dengan pemberitaan Injil yang dikomunikasikan secara kontekstual. Tujuan pelaksanaan misi dan mengkomuniasikan Injil secara kontekstual adalah untuk membawa keselamatan dari Allah yang mentranformasi hidup (Kisah Para Rasul 4:12; II Korintus 5:17). Dapat ditegaskan bahwa pada saat Injil diberitakan dan diterima serta ditanggapi, semuanya terjadi secara kontekstual. Peter Beyerhaus telah mendiskusikan tentang gagasan The Three Selves Formula yang dikembangkan oleh Rufus Anderson dan Henry Venn pada Abad XIX, sebagai sumber teori

\footnotetext{
${ }^{2}$ Yakob Tomatala, Teologi Kontekstualisasi (Suatu Pengantar) (Malang: Gandum Mas, 1993).

${ }^{3}$ Budi Rahmat Hakim, Tekstualisasi Dan Kontekstualisasi Ajaran Islam (Sebuah Wacana Interrelasi Dalam Pemaknaan Al-NusUs Al-Syar'iyyah), Jurnal Al-Hikmah, vol. 15, December 13, 2014, accessed February 8, 2021, http://journal.uin-alauddin.ac.id/index.php/al_hikmah/article/view/408.

${ }^{4}$ Edmund Woga, Dasar-Dasar Misiologi (Yogyakarta: Kanisius, 2002), 13-16; 32-39.

5 Rene Padilla, "The Contextualization of The Gospel," in Readings in Dynamic Indigeneity, ed. Charles H. Kraft and Tom N. Wisley (Pasadena: William Carey, 1979), 286-312.

${ }^{6}$ Woga, Dasar-Dasar Misiologi.

${ }^{7}$ Tomatala, Teologi Kontekstualisasi (Suatu Pengantar); Don Richardson, Anak Perdamaian (Bandung: Kalam Hidup, 1993).
} 
tentang kontekstual dan kontestualisasi serta indigenisasi. ${ }^{8}$ Dalam kaitan ini, penanggapan akan Injil, menyatakan iman serta pemahaman akan TUHAN dari worlview yang tersalut oleh konteks peradaban, kebudayaan, kemasyarakatan, sejarah dari lingkungan yang utuh (holistic). ${ }^{9}$ Dari perspektif ini, dapat dikatakan bahwa penerima Injil sedang berteologi dalam konteks, sehingga kontekstualisasi adalah proses berteologi yang kontekstual. ${ }^{10}$ Teologi dalam arti sempit adalah "refleksi iman kepada yang dipercayai". ${ }^{11}$ Refleksi iman ini terjadi dalam ruang dan waktu yang dikodisikan oleh konteks kehidupan nyata. Dari sini, dapatlah dikatakan bahwa teologi sebagai refleksi iman berhubungan dengan penyataan TUHAN Allah yang dinyatakan dan dipahami secara kontekstual di dalam konteks, di mana dapat dikatakan bahwa pelaksanaan tugas misi, "mengkomunikasikan Injil dan berteologi adalah kontekstual"12 karena sifatnya yang terkondisi oleh konteks kehidupan.

Mengkomunikasikan Injil dan berteologi yang kontekstual berkembang dalam proses kontekstualisasi (penjadian teologi) dan diekspresikan (berteologi) secara kontekstual, sebagai bagian dari kehidupan masyarakat dalam konteks. Istilah kontekstual dalam tulisan ini dipahami sebagai substansi dari semua yang ada dan terjadi dalam lingkup serta konteks kehidupan total, sehingga hakikat teologi adalah kontekstual. Kontekstualisasi lebih berarti "proses berteologi yang terjadi di dalam konteks" atau "doing theology in context." Proses berteologi dipahami sebagai berpikir teologi (thinking theology), mencipta teologi (creating theology) dan melakukan teologi (doing theology) yang terjadi serta terkondisi di dalam konteks kehidupan yang utuh (holistic). Dalam mengembangkan gagasan tentang judul diskursus ini, ada dua pokok yang akan didiskusikan, antara lain: Pertama, Pendekatan kontekstual dalam Tugas Misi; Kedua, Mengkomunikasikan Injil secara Kontekstual Pasca Pandemi Covid-19, yang diakhiri dengan suatu kesimpulan.

\section{Metode}

Penelitian tentang pokok Pendekatan Kontekstual dalam Tugas Misi dan Komunikasi Injil Pasca Pandemi Covid-19 dilakukan dengan menggunakan metode dan gagasan analisis Milles dan Huberman guna menganalisis sumber-sumber pustaka serta artikel media daring terkait, dengan domain pokok kajian. Pendekatan ini diteruskan dengan mendisplai data serta mereduksi gagasan-gasan, guna menetapkan pokok-pokok atau sub-domain-sub-domain yang akan dikaji dan dianasisis untuk disimpulkan. Pendekatan khusus yang digunakan adalah

\footnotetext{
${ }^{8}$ Peter Beyerhaus, "The Three Selves Formula: Is It Built on Biblical Foundations?," International Review of Mission 53, no. 212 (October 1, 1964): 393-407, accessed February 8, 2021, http://doi.wiley.com/10.1111/j.1758-6631.1964.tb02995.x.

${ }^{9}$ Tony Salurante, "Wawasan Dunia Kristen Sebagai Penunjuk Arah Gereja Modern Bermisi," Evangelikal: Jurnal Teologi Injili dan Pembinaan Warga Jemaat 5, no. 1 (January 27, 2021): 16-26, accessed February 8, 2021, https://journal.sttsimpson.ac.id/index.php/EJTI/article/view/328.

${ }^{10}$ Tony Salurante, "Berteologi Global Dan Bermisi Dalam Konteks: Sebuah Usulan Kontekstualisasi Kekristenan Masa Kini,” Ephigraphe 4, no. 2 (2020): 225-235.

${ }^{11}$ Yakob Tomatala, Yesus Kristus Juruselamat Dunia (Jakarta: YT Leadership Foundation, 2004), 1718.

${ }^{12}$ Dharmaputra, Konteks Berteologi Di Indonesia, 9 yang menegaskan bahwa "teologi itu pada hakikatnya adalah kontekstual".
} 
metode analisis studi literatur, yang diawali dengan menghimpun data serta menetapkan fakta seputar pokok inti mengenai "Pendekatan Kontekstual dalam Tugas Misi dan Komunikasi Injil Pasca Pandemi Covid-19" dari literatur terkait, yang merupakan domain kajian ini. Domain ini selanjutnya dibagi ke dalam dua sub-domain, yang menyentuh pokok-pokok berikut: Pertama, Pendekatan Kontektual dalam Tugas Misi; Kedua, Pendekatan Kontekstual dalam Komunikasi Injil pada Konteks Pasca Pandemi Covid-19. Diskusi ini dilakukan dalam dua tahap, yaitu, mengadakan analisis domain, untuk memilah, merinci, memeriksa dengan menggunakan pendekatan berpikir ketat, guna memperoleh arti dan makna dari setiap gagasan tentang "Pendekatan kontekstual dalam tugas misi dan komunikasi Injil secara Kontekstual Pasca Pandemi Covid-19”, dan kemudian, menarik penyimpulan dengan konsekuen-konsekuen atau generalisasi-generalisasi yang merupakan temuan dari pokok kajian ini.

\section{Hasil Dan Pembahasan}

\section{Pendekatan Kontekstual Dalam Tugas Misi}

Teologi Alkitabiah yang kontekstual menjelaskan tentang bagaimana teologi berjadi atau teologi tercipta serta berwujud di dalam konteks kehidupan suatu masyarakat. Secara umum, teologi terjadi, tatkala manusia memandang ke atas kepada yang ilahi, dan menyatakan apa yang dipahami tentang Sang Ilahi. Dalam hubungan ini, teologi disebut berjadi secara Alkitabiah, karena sumbernya adalah Alkitab yang dinyatakan di dalam konteks. Rene Padilla mengatakan bahwa, "The incarnation makes clear God's approach to the revelation of himself and of his purposes: God does not shout his message from the heavens; God becomes present as a man among men. The climax og God's revelation is Emmanuel.",13 Dengan demikian, dapat dikatakan bahwa Teologi Alkitabiah yang kontekstual mengandaikan bahwa teologi yang terwujud dalam konteks diawali dari penyataan TUHAN Allah dari dan di dalam Alkitab serta melalui Alkitab. Mendiskusikan tentang pendekatan kontektual dan kontekstualisasi dalam tugas misi, maka ada dua gagasan yang akan dikembangkan, yaitu: Pertama, Kontekstual dan Kontekstualisasi dalam Berteologi dan Bermisiologi; Kedua, Pendekatan Kontekstual dan Berkontekstualisasi dalam Tugas Misi.

Kontekstual dan Kontekstualisasi dalam Berteologi dan Bermisiologi

Istilah kontekstual melibatkan kata-kata konteks, teks dan kontekstual, serta kontekstualisasi. Istilah ini berasal dari kata konteks, atau context, ${ }^{14}$ yang bersumber dari istilah contextus dan berkembang dari kata dasar contextere, yang arti dasarnya adalah to wave together. Istilah konteks dalam bidang teologi dan misi Kristen telah melibatkan beberapa pengertian. Pengertian itu adalah antara lain, konteks kehidupan georafis-topografis,

\footnotetext{
${ }^{13}$ Padilla, "The Contextualization of The Gospel," 286.

${ }^{14}$ Noah Webster, Webster's New Universal Dictionary of the English Language: Unabridge (Grand Rapids: Webster's universal Press, 1976).
} 
konteks sosial (masyarakat), konteks kebudayaan (cara hidup total masyarakat), dan konteks historis (sejarah kehidupan masyarakat di mana suatu peristiwa terjadi), konteks kerja (tempat di mana suatu pekerjaan dilakukan) dan banyak lagi. Istilah teks, lebih dikaitkan dengan "teks Alkitab", yang berhubungan dengan penyataan dan pernyataan TUHAN Allah dalam konteks. Penyataan (Self Disclosure) dan pernyataan (Self Revelation) melibatkan konteks (tempat) dan kejadian (peristiwa) di mana Firman disabdakan oleh TUHAN Allah. Konteks juga berhubungan dengan waktu di mana suatu peristiwa TUHAN terjadi, yaitu Allah yang menyatakan diri dan bersabda kepada Penulis Alkitab dan tokoh pilihan-Nya. ${ }^{15}$ Istilah kontekstual secara khusus lebih berarti orientasi dan sifat yang berhubungan dengan konteks, dan mengaitkan aspek-aspek konteks. Pada sisi lain, istilah kontekstualisasi lebih cenderung berarti proses berteologi dan bermisiologi dalam konteks. Proses berteologi dan bermisiologi terjadi, baik dalam penjadian (terciptanya teologi) atau proses misi, baik secara konseptual, mau pun praksis. Proses berteologi dalam kontekstualisasi menjelaskan tentang penyattan dan pernyataan TUHAN, penerimaan, pemahaman dan refleksi terhadap Injil atau Firman Allah dan ungkapan pemahaman tentang TUHAN dalam konteks. Allmen mendiskusikan The Birth of Theology, yang menjelaskan bagaimana proses terjadinya orang berteologi dalam suatu konteks. ${ }^{16}$

Dalam hubungan ini, tatkala Firman Allah dinyatakan di suatu konteks, hal ini melibatkan penyataan dan pernyataan Firman ke dalam konteks secara konteksual dan refleksi atas Firman dari konteks yang juga bersifat kontekstual. ${ }^{17}$ Charles Kraft dalam mengulas proses berteologi yang kontekstual ini mengungkapkan bahwa "Berteologi adalah suatu proses yang mengambil tempat pada level perseptual manusia". Bagi Wisley dan Kraft, "Berteologi adalah suatu proses penemuan dinamis yang melibatkan manusia pada level persepsinya."18 Dalam hubungan ini, berteologi yang kontektual menjelaskan tentang pendekatan kontekstualisasi yang memanfaatkan aspek-aspek kebudayaan dari persepsi manusia budaya yang memberi ruang bagi partisipan untuk berefleksi dan menemukan kebenaran Firman Allah dari pesrpektif realitas kebudayaannya. Dalam kaitan ini berteologi yang kontekstual menjelaskan tentang penemuan, penciptaan dan praksis berteologi (thinking theology, creating theology, and doing theology) yang tekstual dan kontekstual Alkitabiah yang memasyarakat dalam konteks. Dalam kaitan ini, Eka Dharmapurta mengatakan bahwa “... pada hakikatnya, teologi tidak lain dan tidak bukan adalah upaya untuk mempertemukan secara dialekttis, kreatif secara esensial antar teks dan konteks, antara kerygma yang universal dengan kenyataan hidup yang kontekstual." ${ }^{19}$ Dalam hubungan ini, dapat dilihat keterkaitan antara "teks Alkitab yang tekstual kontekstual, penyataan dan pernyataan Alkitab dalam konteks yang kontekstual dan refleksi perseptual atas kebenaran Alkitab yang kontekstual.

\footnotetext{
${ }^{15}$ Tomatala, Teologi Kontekstualisasi (Suatu Pengantar), 2-3.

${ }^{16}$ Daniel Allmen, "The Birth of Theology," International Review of Mission 64, no. 253 (January 1, 1975): 37-55, accessed February 8, 2021, http://doi.wiley.com/10.1111/j.1758-6631.1975.tb01155.x.

${ }^{17}$ Tomatala, Teologi Kontekstualisasi (Suatu Pengantar), 2-3.

${ }^{18}$ Tom N. Wisley and Charles H. Kraft, eds., Readings in Dynamic Indigeneity (Pasadena: William Carey Library, 1979), 262.

${ }^{19}$ Dharmaputra, Konteks Berteologi Di Indonesia, 9.
} 
Dari sini dapat ditemukan bahwa teologi yang kontekstual menjelaskan bahwa kontekstualisasi adalah "proses dan metode teologi serta kenyataan berteologi" dalam setiap konteks. Yakob Tomatala menyebut proses kontekstualisasi berteologi bermisiologi ini sebagai "Trialektis Berteologi dalam Konteks" yang melibatkan "konteks Pemberita Firman (Misionari); konteks Firman atau Injil yang kontekstual Hebraik (Yahudi) - Helenis (Yunani), dan konteks Pendengar atau Penerima Firman” (1993:3-4), ${ }^{20}$ yang melahirkan teologi kontekstual yang Alkitabiah dan relevan dalam masyakarat. Gagasan teoritis teologi konteksual yang diungkapkan di sini menekankan bahwa "berteologi (thinking, creating, and doing theology) yang kontekstual Alkitabiah sebagai proses kontekstualisasi yang tekstual kontekstual". Proses kontekstualisasi yang tekstual kontekstual beranjak dari TUHAN Allah, dinyatakan-Nya melalui "penyataan TUHAN" (Self Disclosure) dan "pernyataan FirmanNya" (Self Revelation) ke dalam konteks manusia, yang melibatkan refleksi kristis atas penyataan dan pernyataan Allah. Refleksi kritis ini berdasarkan persepsi nilai kebudayaan yang menggunakan bentuk, arti dan fungsi elemen budaya terpilih yang redemptive, dan membawa transformasi kehidupan (transforming life) yang ditandai penghayatan serta ekspresi Firman dalam konteks yang berpatutan dengan kehidupan nyata, sehingga teologi menjadi relevan.

Pada sisi lain, bermisiologi yang kontekstual menjelaskan tentang proses kontekstualisasi dalam pelaksanaan tugas misi yang tekstual kontekstual. Proses kontekstualisasi dalam tugas misi menjelaskan tentang cara hidup yang kontekstual, dan pendekatan yang kontekstual yang berorientasi kepada kehidupan konteks tugas misi, dan pelayanan yang kontekstual dalam pemberitaan Injil. Proses bermisiologi yang kontekstual dalam kontestualiasisasi lebih berarti bagaimana mengidupi, mengerjakan dan mengkomunikasikan Injil yang kontekstual dalam konteks suatu masyarakat. Yakob Tomatala $^{21}$ menegaskan bahwa "metode misi yang sesungguhnya adalah kontekstual", dengan pendekatan misi yang kontekstual dalam empat tahapan, yaitu: Pertama, Presence, yang menjelaskan tentang cara hidup serta kehadiran Pemberita Firman secara kontekstual (akulturasi), sehingga diterima, dihargai dan menjadi orang dalam (etic), guna menghadirkan (enkulturasi) Injil. Kedua, Proclamation, yaitu memberitakan Injil dengan pendekatan enkulturasi (enculturation) ${ }^{22}$, sehingga pendengar menerima dan memahami serta menyambut kebenaran tentang Yesus Kristus. Ketiga, Persuasion, yaitu tindakan menyakinkan untuk mendorong penerima mengambil keputusan menerima Yesus Kristus sebagai TUHAN dan Juruselamat. Keempat, Incorporation into the Body, yaitu menggerejakan orang percaya baru dalam konteks, dengan tujuan agar mereka bertumbuh dalam iman dan meneruskan Amanat Agung Yesus Kristus. ${ }^{23}$ Tujuan dari pendekatan misi

\footnotetext{
${ }^{20}$ Tomatala, Teologi Kontekstualisasi (Suatu Pengantar), 3-4 Gagasan "Trialektis Berteologi dalam Konteks" ini adalah dasar bagi proses berteologi yagn kontektual dan pelaksanaan tugas misi yagn juga kontekstual, khususnya mengkomunikasikan Ijjil dalam konteks.

${ }^{21}$ Yakob Tomatala, Teologi Misi (Jakarta: YT Leadership Foundation, 2003), 214-225.

${ }^{22}$ Aylward Shorter, Toward a Theology of Inculturation (Eugene, OR: Wipf and Stock Publishers, 2003) Shorter dalam bukunya menjelaskan tentang gagasan inkulturasi seraca intensif.

${ }^{23}$ Tomatala, Teologi Misi, 214-215.
} 
yang kontekstual ialah guna menghadirkan keseimbangan berteologi pada konteks misi. Pendekatan dalam proses bermisilogi yang kontekstual diwujudkan dengan memanfaatkan elemen dan artifak kebudayaan yang familiar dalam masyarakat. Pendekatan ini dilakukan dengan memperhatikan bentuk, arti dan fungsi yang bersifat redemptive untuk dipakai sebagai instrumen misi yang absah Alkitabiah ${ }^{24}$ sehingga berita Injil dapat didaratkan ke dalam konteks di mana tugas misi dilaksanakan, dimana berita Injil diterima, dipahami, dan membawa transformasi serta meneguhkan kehidupan Gereja, ${ }^{25}$ di mana tugas misi dilaksanakan.

\section{Pendekatan Kontekstual dan Berkontektualisasi dalam Tugas Misi}

Pendekatan kontekstual dan berkontektualisasi dalam tugas misi menjelaskan tentang landasan pelaksanaan tugas misi yang kontekstual dan relevan. Pedekatan kontekstual pertama-tama beranjak dari konteks teks Firman yang kontekstual, yang menjelaskan bahwa proses kontekstualisasi yang dimulai dari TUHAN Allah Yang adalah segala-galanya bagi kontekstuaslisasi, dan berkontekstualisasi dalam tugas misi. Tidaklah mengeherankan bahwa J. Herbert Kane mengatakan, "Allah adalah Allah misioner. Alkitab adalah buku misioner. Injil adalah berita misioner. Gereja adalah institusi misioner". ${ }^{26}$ Penegasan ini menjelaskan bahwa TUHAN Allah yang adalah segala-galanya bagi misi-Nya, adalah Sumber, Penggerak, Penguat, Pelaksana dan Penggenap serta Pelaksana bagi misi-Nya. ${ }^{27}$ Berdasarkan hubungan ini, gagasan-gagasan teologis misiologis yang mendasari pendekatan kontekstual dalam kontekstualisasi misi yang bertitik anjak dari TUHAN Allah memasuki dunia manusia, dalam konteks kehidupan yang kontekstual. Perlu ditegaskan bahwa kontekstualisasi sebagai proses berteologi $^{28}$ melibatkan perspektif Allah (Theoprooptiki) yang menjelaskan tentang bagaimana TUHAN bekerja dalam mewujudkan misi-Nya, melalui penyataan dan pernyataan diri-Nya. Dalam hubungan ini, Rene C. Padilla (1975) menegaskan bahwa "tuntunan atas teologi kontekstual yang Injili adalah 1) Firman Allah adalah landasan atau basis bagi teologi; 2) Situasi sejarah yang konkrit adalah konteks teologi; 3) Ketaatan kepada Yesus Kristus adalah tujuan teologi. Kebenaran ini menegaskan bahwa pendekatan misi yang kontektual beranjak dari TUHAN Allah dan masuk ke dalam kehidupan manusia dalam konteks kehidupan yang aktual dan konkrit. Pendekatan teologi dan misiologi yang

\footnotetext{
${ }^{24}$ Tomatala, Teologi Kontekstualisasi (Suatu Pengantar), 39-42 The New Covenanat sebagai Penakar Keabsahan Elemen Budaya bagi Kontekstualisasi.

${ }^{25}$ Alan R. Tippett, Verdict Theology in Missionary Theory (South Pasadena: Lincoln Christian College Press, 1969), 148-163 Dalam kaitan ini, Allan R. Tippett mengulas tentang bagaimana membangun Gereja indigeniti yang kontekstual dalam setiap konteks, agar Gereja menjadi relevan dan dapat bertumbuh sebagaimana mestinya dalam setiap konteks.

${ }^{26}$ J. Herbert Kane, Understanding Christian Missions (Grand Rapids: Baker Book House, 1981), 15.

${ }^{27}$ Tomatala, Teologi Kontekstualisasi (Suatu Pengantar), 16-17.

${ }^{28}$ Tomatala, Yesus Kristus Juruselamat Dunia, 18-20 Di sini ditegaskan bahwa "teologi adalah teologi, karena mengarahkan pandangan manusia kepada Allah/ TUHAN (Yang Ilahi)”. ... Dalam kaitan ini, teologi menempatkan "Alkitab yang adalah penyataan dan pernyataan Allah" dalam perspektif iman itu sendiri, berdasarkan premis bahwa "Alkitab adalah Firman Allah". Dengan demikian, dapat dikatakan bahwa apabila seorang Kristen memikirkan tentang Allah berdsarkan apa yang dinyatakan Alkitab dan mengungkapkan pemahamannya maka ia sedang berteologi.
} 
konteksual ini bersifat inkarnatif, ${ }^{29}$ diawali dari tindakan TUHAN dalam mewujudkan rancangan misi-Nya, masuk ke dalam dunia, guna menggapai manusia di dalam konteks kehidupan yang utuh. Pada sisi lain, pendekatan ini memperlihatkan bahwa teologi mau pun misiologi memperoleh tempat dalam perspektif manusia (antropoprooptiki). Hal ini menjelaskan bagaimana manusia berinteraksi dan menerima penyataan serta pernyataan Allah dan mengkspresikan pemahamannya akan TUHAN secara kritis dari dan melalui konteks hidupnya. Dari uraian ini, terlihat bagaimana seharusnya merumuskan teologi dan misiologi yang kontekstual Alkitabiah, melibatkan dua aksis, yaitu TUHAN dan manusia, guna memahami bagaimana pendekatan kontekstualisasi beroperasi dan berinteraksi secara dinamis.

\section{Mengkomunikasikan Injil Secara Kontekstual Pasca Pandemi Covid-19}

Telah diuraikan bahwa teologi sejatinya adalah kontekstual, dan berteologi dalam konteks melibatkan proses kontekstualisasi. Prinsip yang sama berlaku bagi pendekatan misi dan misiologi yang juga kontekstual dalam proses kontekstualisasi yang melibatkan dinamika interaksi antara "Fiman dan manusia, Logos yang Kekal dan manusia yang temporal" dalam konteks kehidupannya. Interaksi kontekstualisasi menempatkan komunikator misi untuk berperan sebagai jembatan pengantara guna mengkomunikasikan Injil. Membahas pokok seputar mengkomunikasikan Injil secara Kontekstual Pasca Pandemi Covid-19, maka -pokokpokok yang dibahas, adalah: Pertama, Dasar-dasar Komunikasi Injil yang Kontekstual; dan Kedua, Kontekstualisasi Komunikasi Injil pada Masa Pasca Pandemi Covid-19.

Dasar-dasar Komunikasi Injil yang Kontekstual

Dasar komunikasi Injil. Menjelaskan tentang bagaimana Injil berinteraksi ke dalam konteks, Louis J. Luzbetak (1988:75-78) menegaskan bahwa "Dalam terma-terma antropologi, tatkala Kristus berinkarnasi (berkontekstualisasi) ke dalam suatu cara hidup ( $a$ lifeway) budaya, kenyataan ini tidak semata-mata terakomodasi, karena Injil terintegrasi dengan keseluruhan aspek kebudayaan di mana sasarannya adalah agar Injil menjadi bagian integral dari sistem kebudayaan." Dalam hal ini, tujuan dan fokus utama dari proses kontektual dan kontekstualisasi Injil yang integral guna memastikan bahwa Injil dapat diterima sebagai bagian dari kebudayaan, dan Yesus Kristus diakui sebagai "Pusat atau Core Center" dari kontekstualisasi. Dalam meletakkan dasar-dasar bagi kontekstualisasi Injil yang kontekstual, maka proses kontekstualisasi beroperasi dalam tiga level, yaitu: Pertama, Level kontekstualisasi teologisasi-misiologisasi (Theologizing Missiologizing Contextualization Level). Level ini menjelaskan bahwa "Injil (Allah) yang dari atas" bekerja di dalam serta melalui kebudayaan" dengan menyentuh aspek-aspek terkait di dalamnya. ${ }^{30}$ Proses ini menjelaskan bahwa Injil Allah (Roma 1:16-17) yang berkontekstualisasi ke dalam konteks

\footnotetext{
${ }^{29}$ Tomatala, Teologi Kontekstualisasi (Suatu Pengantar), 21-31.

${ }^{30}$ Charles H Kraft, Christianity In Culture: A Study In Biblical Theologizing In Cross-Cultural Perspective, 25th Annv. (Maryknoll, N.Y: Orbis Books, 2005), 103-115.
} 
kebudayaan, memanfaatkan aspek-aspek bentuk, arti dan fungsi budaya secara menyeluruh, guna mendaratkan Injil. Dipahami bahwa aspek-aspek kebudayaan terikat secara terintegrasi dalam suatu sistem, yang mengharuskan adanya pembedaan dan pemilahan bentuk, arti dan fungsi yang analogis redemptive (redemptive analogy), ${ }^{31}$ yang dapat merepresentasi makna yang Alkitabiah guna menghadirkan Injil Yesus Kristus, sehingga berterima dalam setiap konteks. Kedua, Level Inkarnasi (Incarnation Level). Level inkarnasi, adalah tahapan pendekatan yang menyentuh inti kebudayaan atau worldview yang mewujudkan transformasi kehidupan. ${ }^{32}$ Penyentuhan worldview menjelaskan proses Injil bekerja dalam menghadirkan (menginkarnasikan) Yesus Kristus dalam kebudayaan. Pendekatan ini berhubungan dengan bagaimana menggunakan bentuk, arti dan fungsi elemen budaya terpilih yang dimaknakan secara tepat dalam konteks sehingga menghadirkan "Yesus Kristus Alkitab" secara tepat dan disambut dalam setiap konteks. Penyentuhan worldview pada level inkarnasi berhubungan dengan pembaruan nilai dan fungsi dari setiap elemen, sehingga Yesus Kristus memperoleh sambutan dalam konteks. Fokus terpenting dari level inkarnasi adalah menghadirkan Kristus untuk diterima dan membawa transformasi kehidupan manusia berdosa dalam masyarakat di mana tugas misi dijalankan. Pendekatan inkarnatif beroperasi secara tersistem yang dinamis (dynamic systematic whole), ${ }^{33}$ dengan memanfaatkan model dinamika kesejajaran (dynamic equivalence theologizing missiologizing) dalam menghadirkan Injil (Yesus Kristus) pada setiap konteks, untuk menghadirkan makna Injil dan Yesus Kristus yang otentik Alkitab, dan yang sejajar sama seperti pada teks konteks asli di mana Alkitab (Injil) terhadirkan dalam sejarah, sehingga makna Injil menjadi relevan dalam konteks budaya kekinian dengan dampak transformatif yang positif. ${ }^{34}$ Ketiga, Level kritis atas mentalitas kebudayaan (Integrative Critical Cultural Mentality Level). Gagasan ini dikemukakan oleh Paul G. Hiebert (1989:186-192), yang mengedepankan "kontekstualisasi kritis" (critical contextualization) dalam proses kontekstualisasi berdasarkan kenyataan, bahwa setiap manusia budaya terkondisi dengan kebudayaan dan worlview budayanya. Keterkondisian ini menjelaskan bahwa manusia budaya memiliki serta membawa serta nilai-nilai baku yang harus disikapi secara kritis dalam penghadiran Injil Yesus Kristus. Nilai-nilai baku ini menyertakan aspek mentalitas dan psikologi kebudayaan yang melekatkan kebiasaan serta cara hidup manusia budaya dari setiap konteks. Mentalitas psikologi kebudayaan dari cara hidup dan kebiasaan dapat disebut sebagai mentalitas psikologi kebudayaan lama. Mentalitas psikologi kebudayaan lama ini mengandung nilai-nilai worldview kebudayaan yang dapat, atau tidak berkepatutan dengan nilai Alkitab. Prinsip ini menegaskan bahwa dalam proses kontekstualisasi Injil, perlu diadakan analisa kritis tentang hakikat dan kadar mentalitas psikologi kebudayaan lama yang mempengaruhi kebiasaan secara negatif. Tujuan analisis

${ }^{31}$ Tomatala, Teologi Kontekstualisasi (Suatu Pengantar), 34-44.

${ }^{32}$ Ibid., 61-71 Di sini, worldview dimaknakan sebagai pusat pembakuan dan institusionalisasi nilainilai budaya yang menjadi cara hidup total (total lifeway), pandangan hidup (reality and perception) serta sikap hidup (cultural habits and attitude) manusia budaya dalam setiap kelompok masyarakat.

${ }^{33}$ Louis J. Luzbetak, The Church and Cultures: New Perspectives in Missiological Anthropology (New York: Orbis Books, 2015), 78.

${ }^{34}$ Kraft, Christianity In Culture, 261-312. 
kritis adalah untuk meletakkan landasan guna menghadirkan transformasi kehidupan Kristen yang tuntas dari kehidupan peserta budaya. Paul G. Hiebert ${ }^{35}$ menganjurkan beberapa pendekatan kritis Alkitabiah yang harus diperhitungkan dalam proses kontekstualisasi Injil, antara lain, yaitu: 1) Setiap orang Kristen dalam konteks kebudayaan di mana tugas misi dijalankan harus diteguhkan untuk berkesadaran bahwa mereka memerlukan penerapan nilai Alkitabiah dalam semua aspek kehidupan. Mereka perlu diteguhkan untuk mampu menilai semua aspek kebudayaan mereka secara kritis, guna menerapkan cara hidup dan kebiasaan baru sesuai dengan nilai-nilai luhur Alkitab. Mereka juga harus direvitaslisasi untuk menjawab pertanyaan, "apakah bentuk, nilai, dan kegunaan elemen-elemen kebudayaan yang mereka pegang dan lakukan, sesuai dengan kebenaran Alkitab ataukah tidak". Dalam kaitan ini, perlu diadakan dialog terbuka antara pemberita dan penerima Injil, dengan mengingat bahwa dalam temuan penelitian, hampir $92 \%$ dari elemen kebudayaan dapat diterima dan digunakan. Ada sekitar 6\% dari elemen budaya yang harus ditampih dan dimodifikasi karena mengadung konotasi kepercayaan budaya lama yang sinkritis, yang dilakukan dengan menggunakan "unsur pengganti" (functional substitute) untuk membangun kebiasaan baru yang Alkitabiah. Di samping itu, ada kira-kira 2\% dari elemen budaya lama yang harus ditolak, karena mengandung unsur serta nilai kepercayaan lama yang okultistis, dan animistis. ${ }^{36}$ 2) Mengadakan dialog kritis konstrukstif di mana Pembawa dan Penerima Injil harus terbuka dan bersikap kristis serta inovatif terhadap kebiasaan bawaan yang tidak berkesesuaian dengan ajaran Alkitab. Dialog ini harus diadakan secara terbuka sebagai upaya untuk menemukan bentuk kebiasaan baru yang Alkitabiah dan kontesktual untuk disepakati serta diterapkan secara bersama dalam membangun kehidupan Gereja sebagai komunitas baru, yang berpusatkan Kristus untuk diamalkan dalam konteks kehidupan misi. 3) Para Pemberita Injil harus mengamati dan menemukan praktek inkulturasi kebudayaan (sosialisasi) yang positif dalam masyarakat, guna meletakkan landasan bagaimana menerapkan ajaran Injil secara relevan dalam konteks, guna mendewasakan iman dan pelayanan Kristen. 4) Pemberita Injil dan Penerima harus secara terbuka mengevaluasi kebiasan-kebisaan budaya lama yang dipraktekkan, guna memilah, dan memastikan manfaat serta dampak penggunaannya dalam kehidupan Kristen baru, sehingga terjadi perubahan kehidupan komunitas secara konstruktif. 5) Dalam proses kontekstualissi, Pemberita Injil harus berupaya bersikap kritis terhadap pandangan hidup serta nilai-nilai kebudayaannya, dan mengedepankan ajaran Alkitab yang benar demi menetapkan teologi dan pendekatan kontekstual Alkitabiah yang sahih, ${ }^{37}$ dan membiarkan penerima Injil membuat keputusan untuk menerapkan nilai Alkitab secara tepat dalam konteks kehidupan Kristen yang baru.

Komunikasi dalam kebudayaan. Menjelaskan tentang komunikasi Injil dalam kebudayaan, Yakob Tomatala (2007:219-224), mengatakan bahwa "istilah komunikasi

\footnotetext{
${ }^{35}$ Paul G. Hiebert, Anthropological Insights for Missionaries (Grand Rapids: Baker Academic, 1985); Paul G. Hiebert, The Gospel in Human Contexts: Anthropological Explorations for Contemporary Missions (Grand Rapids: Baker Publishing Group, 2002).

${ }^{36}$ Tomatala, Teologi Kontekstualisasi (Suatu Pengantar), 40-42.

${ }^{37}$ Ibid., 74-75.
} 
berasal dari kata Latin communicare, yang berarti "menyerahkan, membagi atau memberi". Istilah komunikasi memberntuk kata komunis, yang berarti sama atau umum. Dengan demikian, istilah komukasi dapat diartikan sebagai "memberi sesuatu untuk membangun atau mencipta atau membawa kesamaan (pandangan, pengertian, dsb) secara umum dengan seseorang". Dalam kaitan ini, dapat dikatakan bahwa "komunikasi adalah hubungan", yang melibatkan proses individu dalam masyarakat. ${ }^{38}$ Dalam kaitan ini, elemen komunikasi adalah Pembicara (Komunikator yang berperan sebagai decoder), Berita atau Informasi atau Pesan, dan disalurkan melalui Media (lisan, tulisan, elektronik, teknologi komunikasi, dsb), serta Penerima (Komunikan, yang berperan sebagai encoder), serta proses Transmisi Arti Pesan yang dikomunikasikan. ${ }^{39}$ Dalam mengkomunikasikan Injil secara kontekstual, ada tiga tugas yang harus diperhatikan oleh Komunikator dalam menyusun dan meyampaikan pesan, ${ }^{40}$ antara lain yaitu: 1) Tugas "menterjemahkan pesan" secara dynamic equivalence, untuk "penyamaan makna" Alkitab, Komunikator dan Pendengar atau Penerima Injil; 2) Tugas transkulturasi pesan untuk "menyiapkan berita yang dynamic equivalence" guna ditransmisikan secara kontekstual; dan 3) Tugas penyampaian pesan yang dynamic equivalenve theologizing missiologizing yang disampaikan dengan menggunakan media yang kontekstual dan relevan, sehingga pesan terdecoding dan terencoding dengan tepat.

Menerapkan prinsip-prinsip di atas dalam komunikasi kontekstual, Tomatala mengetengahkan beberapa pendekatan komunikasi Injil yang kontekstual dalam proses kontekstualisasi. ${ }^{41}$ Prinsip-prinsip komunikasi kontektual itu adalah antata lain: Pertama, Prinsip Komunikasi bagi Komunikator Injil. 1) Proses kontekstualisasi menuntut agar setiap Komunikator menyadari bahwa ia terkondisi oleh kebudayaannya, sehingga ia harus mengosongkan diri dari pengaruh budaya bawaannya, guna memahami makna berita Firman Allah yang tekstual dalam konteks Alkitab, dan cara pandang penerima Injil secara otentik, sebagai dasar untuk menjembatani komunikasi injil secara benar. 2) Dalam proses kontekstualisasi, Komunikator Injil harus berorientasi kepada Penerima dengan cara hidup kebudayaannya secara menyeluruh, untuk membangun pemahaman yang benar tentang bagaimana membuat diri diterima dalam kontekas misi. 3) Dalam proses komunikasi Injil yang kontektual, Komunikator harus menempatkan diri dan berupaya memahami suatu teks Alkitab secara tekstual dalam matriks budaya Alkitab, dan mencari kesesuaian gagasan dengan konsep budaya penerima, guna menyeberangkan berita Injil secara tepat. 4) Dalam proses mengkomunikasikan Injil, Komunikator perlu secara terus menerus mempelajari dinamika komunikasi lintas budaya dengan pendengar, untuk "belajar beradaptasi" bagaimana mengemas dan menyampaikan suatu berita Alkitabiah memanfaatkan bentuk, arti, dan fungsi elemen budaya yang tepat secara dynamic equivalence, untuk mengkomunikasikan Injil. Kedua, Prinsip Dasar Komunikasi Injil. Prinsip dasar

\footnotetext{
${ }^{38}$ Yakob Tomatala, Antropologi Kebudayaan (Jakarta: YT Leadership Foundation, 2007), 219.

${ }^{39}$ Ibid., 220-221.

${ }^{40}$ Kraft, Christianity In Culture, 261-305 Gagasan tugas komunikasi kontekstual ini dikembangkan dari pendapat Kraft.

${ }^{41}$ Tomatala, Teologi Kontekstualisasi (Suatu Pengantar).
} 
mengkomunikasikan Injil yang kontekstual adalah antara lain: 1) Komunikator harus menyadari bahwa tujuan komunikasi Injil adalah membuat penerima mengeri, mamahami, dan menerima (decoding) berita (pesan) yang disampaikan (encoding) dan mendorong agar pendengar bertindak sesuai dengan apa yang diinginkan dari pesan yang akan dikomunikasikan. 2) Dalam proses komunikasi Injil, Komunikator harus menyadari bahwa "pengetian penerima bergantung sepenuhnya pada apa yang dimengerti". Dalam hal ini, Komunikator harus berupaya mengerti bagaimana penerima mengerti pesan yang disampaikan, untuk menemukan cara yang tepat dalam berkomunikasi. 3) Komunikator dalam mengkomunikasikan Injil harus memanfaatakan bentuk simbol-simbol budaya komunikasi yang dikenal, sebagai simbol arti dan peran dari pesan yang disampaikan, sehingga berita dapat berterima oleh pendengar. 4) Komunikator harus konsisten berorientasi kepada pendengar dalam proses komunikasi untuk memastikan bahwa informasi atau pesan (berita) Injil yang disampaikan terkomunikasikan secara efektif, yang terbukti dari respon penerima. 5) Komunikator yang menghendaki impak komunikasi berita Injil, harus menggunakan pendekatan "psikologi pendengar" sebegitu rupa, sehingga dapat membangun persuasi yang menggerakkan pendengar untuk membuat keputusan. 6) Komunikator Injil harus merekayasa gaya komunikasi yang bersifat "person to person" sehingga pendengar merasa dihargai, diperhatikan dan terbuka untuk meresponi berita Injil. 7) Komuniktor harus menyediakan landasan bagi efektifitas komunikasi, dengan membangun "kesamaan persepsi" berita Alkitab, pemahaman Komunikator dan perspektif penerima, sehingga berita yang dikomunikasikan menjadi jelas dan dapat diterima serta diresponi dengan baik serta tepat oleh pendengar sehingga mencapai tujuan misional.

\section{Kontekstualisasi Komunikasi Injil pada Masa Pasca Pandemi Covid-19}

Kontekstualisasi Injil dibangun di atas prinsip-prinsip universal dan prinsip-prinsip komunikasi dalam konteks kebudayaan. Prinsip-prinsip kontekstualisasi dan prinsip komukasi Injil yang universal ini berlaku untuk segala situasi, termasuk saat Pra-pandemi Covid-19, masa aktif Pandemi Covid-19, mau pun masa pasca Pandemi Covid-19. ${ }^{42}$ Indikator dari faktor-faktor pengaruh bagi penerapan komunikasi Injil yang kontekstual terletak pada aspek "disrupsi peradaban dengan teknologi" sebagai ujung tombaknya. ${ }^{43}$ Dalam hubungan ini, dipahami bahwa teknologi informasi komunikasi berfungsi dominan dalam proses komunikasi, khususnya pada masa Pandemi Covid-19, dan diduga bahwa aspek teknologi informasi komunikasi dalam komunikasi umum mau pun dalam melaksanakan tugas misi,

\footnotetext{
${ }^{42}$ Michael Teng and Carmia Margaret, "Sketsa Pelayanan Gereja Sebelum, Selama, Dan Sesudah Masa Pandemi COVID-19," Veritas: Jurnal Teologi dan Pelayanan 19, no. 2 (December 31, 2020): 201-213, accessed February 8, 2021, https://doi.org/10.36421/veritas.v19i2.432 Mengulas tentang Sketsa Pelayanan Gereja Sebelum, Selama dan Sesudah Pandemi COVID-19., yang memberikan gambaran bagaimana melaksanakan pelayanan Gereja secara relevan, dalam situasi pengaruh Pandemi Covid-19.

${ }^{43}$ Daniel Ronda, "Kepemimpinan Kristen Di Era Disrupsi Teknologi," Evangelikal: Jurnal Teologi Injili dan Pembinaan Warga Jemaat 3, no. 1 (January 2019): 1-8, accessed February 5, 2019, https://journal.sttsimpson.ac.id/index.php/EJTI/article/view/125 Membahas tentang Kepemimpinan dan Disrupsi Teknologi., yang mengungkapkan tentang pengaruh disrupsi teknologi dalam kepemimpinan Kristen, dalam menopang kepemimpinannya.
} 
akan sangat mungkin terus berlanjut pada masa Pasca Covid-19. Pemanfaatan teknologi menjadi ujung tombak dalam komunikasi Injil, sebagaimana dalam paparan Diana ${ }^{44}$ tentang komunikasi Injil, kemudian Widjaja et al. ${ }^{45}$ dan Sumaryanto dan Adji ${ }^{46}$ yang menunjukkan bahwa pemanfaatan teknologi informasi dan komunikasi dalam mengkomunikasikan Injil akan tetap diperlukan dan terus direlevansikan pemanfaatannya sesuai dengan perkembangan serta kemajuan dan kecanggihan teknologi, khususnya teknologi komuniaksi dan informasi.

Mengamati perkembangan peradaban yang mempengaruhi setiap kebudayaan, dapat ditegaskan bahwa teknologi menempati peran penting dalam membawa perubahan. Pengaruh teknologi ini bukan saja sebagai indikator kemajuan peradaban dan kebudayaan, tetapi juga sebagai pengaruh terhadap kebiasaan sosial yang turut berubah dan mempengaruhi serta membawa perubahan dalam masyarakat. ${ }^{47}$ Memahami pengaruh teknologi terhadap kebudayaan dan kebiasaan sosial masyarakat, dapat dikatakan bahwa teknologi informasi dan komunikasi memiliki andil yang besar dalam membawa perubahan perilaku sosial yang tampak pada interaksi dan inter-komunikasi manusia pada setiap masyarakat. Pengaruh ini melibatkan semua masyakarat dalam lokus sosial budaya, termasuk masyarakat Kristen. Berkenan dengan kenyataan ini dapat dipahami, bahwa kemajuan teknologi informasi komunikasi pada Abad XXI telah berada pada puncak perkembangan yang spektakuler. Dalam kaitan ini, sudah dapat diduga akan pengaruh teknologi informasi komunikasi tehadap kehidupan manusia, yang diindikasikan dengan terjadinya perubahan relasi sosial di antara sesama anggota masyarakat, baik individu, keluarga dan kelompok.

Pada sisi lain, dapat diidentifikasi pengaruh dan pemanfaatan teknologi informasi komunikasi yang telah ditriger oleh Pandemi Covid-19, yang membawa perubahan dalam pola interaksi sosial dan cara berkomunikasi. ${ }^{48}$ Menganalisis pemanfaatan teknologi informasi komunikasi dalam pelayanan dan komunikasi misi pada masa sebelum Pandemi Covid-19, masa berlangsungnya Pandemi Covid-19 dan masa pasca Pandemi Covid-19 yang belum dapat dipastikan kapan akan berakir, maka dapat dikatakan bahwa Covid-19 yang membawa perubahan pola komunikasi sosial, menuntut kesadaran berikut: 1) Perlunya sikap terbuka dan proaktif untuk memanfaatkan teknologi komunikasi informasi dalam tugas misi. 2) Perubahan akibat Covid-19 menjelaskan bahwa pengalaman pelayanan misi pra Pandemi Covid-19 bersifat komunikasi tradisional, di mana TIK berfungsi sebagai alat komunikasi umum. Namun dalam masa pengaruh Pandemi Covid-19 yang sedang berlangsung, tenyata

\footnotetext{
${ }^{44}$ Ruat Diana, "Peran Komunikator Kristen Dalam Strategi Pekabaran Injil Di Era Revolusi Industri 4.0," Integritas: Jurnal Teologi 1, no. 1 (June 2019): 66-73, accessed March 19, 2020, http://journal.sttjaffrayjakarta.ac.id/index.php/JI/article/view/3.

${ }^{45}$ Fransiskus Irwan Widjaja et al., "Menstimulasi Praktik Gereja Rumah Di Tengah Pandemi Covid19," Kurios (Jurnal Teologi dan Pendidikan Agama Kristen) 6, no. 1 (April 30, 2020): 127-139, accessed September 30, 2020, http://www.sttpb.ac.id/e-journal/index.php/kurios.

46 Thomas Onggo Sumaryanto and Hariawan Adji, "Persekutuan Umat Allah Di Dalam Cyberspace," Jurnal Teologi Kontekstual Indonesia 1, no. 2 (January 10, 2020): 127, accessed February 8, 2021, https://journal.sttsimpson.ac.id/index.php/.

47 Tomatala, Antropologi Kebudayaan, 192-203.

${ }^{48}$ Yakob Tomatala, "Gereja Yang Visioner Dan Misioner Di Tengah Dunia Yang Berubah," Integritas: Jurnal Teologi 2, no. 2 (December 31, 2020): 138, accessed February 8, 2021, http://journal.sttjaffrayjakarta.ac.id/index.php/JI/article/view/48.
} 
bukan saja terjadi perubahan pola komunikasi sosial, tetapi juga mempengaruhi pola komunikasi khusus dalam pelayanan Gereja dan misinya. 3) Perlu disadari bahwa pada masa pra Covd-19, orang dapat berinteraksi dengan bebas, tetapi pada masa Pandemi Covid-19, komukasi sosial tatap muka yang langsung telah berubah, di mana TIK berperan besar sebagai media informasi komunikasi yang dominan, sehingga komunikator Injil harus merekayasa pendekatan kekinian yang kontekstual relevan.

Menyikapi uraian tentang "Kontekstualisasi Komunikasi Injil dalam Masa Pasca Pandemi Covid-19", maka beberapa analisis kritis dapat dikemukakan: Pertama, Prinsip kontekstual dan kontekstualisasi Alkiabiah dan prinsip komunikasi misi adalah universal yang tetap berlaku pada segala masa. Namun, pengaruh Pandemi Covid-19 telah membawa perubahan pola hubungan sosial dan pola komunikasi antar individu dalam masayarakat, yang menuntut adanya penyesuaian pemahaman dan sikap tentang bagaimana memanfaatkan prisip komunikasi kontekstual dalam kontekstualisasi komunikasi misi pada kondisi kekinian. Kedua, Perubahan pola interaksi sosial akibat pengaruh Pandemi Covid-19 telah turut mengubah pola komunikasi misi. Perubahan ini menuntut perlunya upaya untuk menganalisis bagaimana menerapkan pola kontekstualisasi komunikasi dalam konteks pengaruh Pandemi Covid-19, guna menemukan implikasi bagi pendekatan kontekstualisasi tugas misi yang relevan pada masa kini, dan dampaknya sesudah Pandemi Covid-19 mereda. Ketiga, Kondisi pengaruh Pandemi Covid-19 pada masa kini diduga akan berpengaruh terhadap pola dan proses komunikasi kontekstual pada masa pasca Covid-19. Sikap asertif yang perlu dikedepankan ialah bahwa para komunikator misi haruslah sensisitf akan dampak perubahan dalam pola hubungan serta pola komunikasi masyarakat, pada masa Pandemi Covid-19 sekarang ini, untuk memastikan dampaknya bagi kontekstualisasi komunikasi misi, dan bagaimana melaksanakan tugas misi pada masa kini. Pemahaman serta sikap ini kiranya menjadi tolok ukur akan kadar pengaruh Pandemi Covid-19 terhadap kontekstualisasi tugas misi pada pasa pasca Covid-19, dan dampaknya pada pendekatan kontekstualisasi misi pada masa depan. Keempat, Dapat diduga bahwa pebubahan pola interaksi dan pola komunikasi berkat kecanggihan TIK pada masa Covid-19 sekarang ini akan tetap berlangsung untuk waktu yang panjang, dengan pola yang terus berubah, sejalan dengan pengaruh disrupsi peradaban dan disrupsi teknologi informasi komunikasi yang terus berkembang pada masa yang akan datang. Kelima, Melihat analisis di depan, para komunikator Injil dalam tugas misi perlu "bersikap antsipatif untuk merumuskan strategi misi baru" yang sesuai dengan perubahan dalam upaya membangun pendekatan komunikasi kontekstualisasi yang relevan dalam pelasksanaa tugas misi pada masa Pasca Pandemi Covid-19 yang akan datang.

\section{Kesimpulan}

Mendiskusikan pokok Pendekatan Kontekstual dalam Tugas Misi dan Komunikasi Injil Pasca Pandemi COVID-19, yang menyentuh dua sub-bahasan, yaitu Pertama, Pendekatan Kontektual dalam Tugas Misi; Kedua, Pendekatan Kontekstual dalam Komunikasi Injil pada Konteks Pasca Pandemi Covid-19, maka ada beberapa proposisi: 
Pertama, Pendekatan Kontektual dalam Tugas Misi yang dibangun di atas kebenaran Alkitab menegaskan bahwa prinsip-prinsip kontekstualisasi Injil dalam tugas misi bersifat universal yang dapat diterapkan pada segala masa. Prinsip komunikasi Injil dalam tugas misi melibatkan prinsip Kontekstual dan Kontekstualisasi dalam Berteologi dan Bermisiologi; yang merupakan metode teologi dan metode bermisiologi yang bersifat universal serta berlaku umum untuk segala masa dan tempat. Pada sisi lain, Metodologi Pendekatan Kontekstual dan Berkontekstualisasi dalam Tugas Misi yang dikembangkan dalam kajian ini, juga bersifat universal dan berlaku umum, namun penerapan dan penggunaannya pada setiap konteks menuntut digunakannya pendekatan kontekstual kekinian dalam berkontekstualisasi.

Kedua, Pendekatan Kontekstual dalam Komunikasi Injil pada Konteks Pasca Pandemi Covid-19 dibangun di atas Dasar-dasar Komunikasi Injil yang Kontekstual berlandaskan prinsip-prinsip kontektaktualisasi komunikasi universal yang telah diuraikan sebelumnya. Dasar-dasar ini menjadi landasan operasional Kontekstualisasi Komunikasi Injil pada Masa sebelum Vovid-19, masa Covid-19 dan Pasca Pandemi Covid-19. Prinsip dan kenyataan ini menuntut kesadaran dari para Komunikator misi untuk bersikap terbuka, proaktif dan antisipatif serta adaptif, guna merekayasa strategi penerapan komunikasi Injil kontekstual yang relevan dan tepat terap, berkesesuaian dengan kondisi konteks misi yang terus berubah akibat disrupsi peradaban dan disrupsi teknologi dalam perjalanan sejarah kebudayaan setiap masyarakat, khususnya pada masa pasca Pandemi Covid-19 Abad XXI.

\section{Rujukan}

Allmen, Daniel. “The Birth of Theology.” International Review of Mission 64, no. 253

(January 1, 1975): 37-55. Accessed February 8, 2021.

http://doi.wiley.com/10.1111/j.1758-6631.1975.tb01155.x.

Beyerhaus, Peter. "The Three Selves Formula: Is It Built on Biblical Foundations?"

International Review of Mission 53, no. 212 (October 1, 1964): 393-407. Accessed

February 8, 2021. http://doi.wiley.com/10.1111/j.1758-6631.1964.tb02995.x.

Dharmaputra, Eka. Konteks Berteologi Di Indonesia. Jakarta: BPK Gunung Mulia, 1991.

Diana, Ruat. "Peran Komunikator Kristen Dalam Strategi Pekabaran Injil Di Era Revolusi

Industri 4.0.” Integritas: Jurnal Teologi 1, no. 1 (June 2019): 66-73. Accessed March

19, 2020. http://journal.sttjaffrayjakarta.ac.id/index.php/JI/article/view/3.

Hakim, Budi Rahmat. Tekstualisasi Dan Kontekstualisasi Ajaran Islam (Sebuah Wacana

Interrelasi Dalam Pemaknaan Al-NusUs Al-Syar'iyyah). Jurnal Al-Hikmah. Vol. 15,

December 13, 2014. Accessed February 8, 2021. http://journal.uin-

alauddin.ac.id/index.php/al_hikmah/article/view/408.

Hiebert, Paul G. Anthropological Insights for Missionaries. Grand Rapids: Baker Academic, 1985.

- The Gospel in Human Contexts: Anthropological Explorations for Contemporary

Missions. Grand Rapids: Baker Publishing Group, 2002.

Kane, J. Herbert. Understanding Christian Missions. Grand Rapids: Baker Book House, 
1981.

Kraft, Charles H. Christianity In Culture: A Study In Biblical Theologizing In Cross-Cultural Perspective. 25th Annv. Maryknoll, N.Y: Orbis Books, 2005.

Luzbetak, Louis J. The Church and Cultures: New Perspectives in Missiological Anthropology. New York: Orbis Books, 2015.

Padilla, Rene. "The Contextualization of The Gospel." In Readings in Dynamic Indigeneity, edited by Charles H. Kraft and Tom N. Wisley, 286-312. Pasadena: William Carey, 1979.

Richardson, Don. Anak Perdamaian. Bandung: Kalam Hidup, 1993.

Ronda, Daniel. "Kepemimpinan Kristen Di Era Disrupsi Teknologi.” Evangelikal: Jurnal Teologi Injili dan Pembinaan Warga Jemaat 3, no. 1 (January 2019): 1-8. Accessed February 5, 2019. https://journal.sttsimpson.ac.id/index.php/EJTI/article/view/125. Salurante, Tony. "Berteologi Global Dan Bermisi Dalam Konteks: Sebuah Usulan Kontekstualisasi Kekristenan Masa Kini.” Ephigraphe 4, no. 2 (2020): 225-235.

__. "Wawasan Dunia Kristen Sebagai Penunjuk Arah Gereja Modern Bermisi."

Evangelikal: Jurnal Teologi Injili dan Pembinaan Warga Jemaat 5, no. 1 (January 27, 2021): 16-26. Accessed February 8, 2021.

https://journal.sttsimpson.ac.id/index.php/EJTI/article/view/328.

Shorter, Aylward. Toward a Theology of Inculturation. Eugene, OR: Wipf and Stock Publishers, 2003.

Sumaryanto, Thomas Onggo, and Hariawan Adji. "Persekutuan Umat Allah Di Dalam

Cyberspace.” Jurnal Teologi Kontekstual Indonesia 1, no. 2 (January 10, 2020): 127.

Accessed February 8, 2021. https://journal.sttsimpson.ac.id/index.php/.

Teng, Michael, and Carmia Margaret. "Sketsa Pelayanan Gereja Sebelum, Selama, Dan

Sesudah Masa Pandemi COVID-19." Veritas: Jurnal Teologi dan Pelayanan 19, no. 2

(December 31, 2020): 201-213. Accessed February 8, 2021.

https://doi.org/10.36421/veritas.v19i2.432.

Tippett, Alan R. Verdict Theology in Missionary Theory. South Pasadena: Lincoln Christian College Press, 1969.

Tomatala, Yakob. Antropologi Kebudayaan. Jakarta: YT Leadership Foundation, 2007. - "Gereja Yang Visioner Dan Misioner Di Tengah Dunia Yang Berubah.” Integritas: Jurnal Teologi 2, no. 2 (December 31, 2020): 127-139. Accessed February 8, 2021. http://journal.sttjaffrayjakarta.ac.id/index.php/JI/article/view/48.

—. Teologi Kontekstualisasi (Suatu Pengantar). Malang: Gandum Mas, 1993.

—. Teologi Misi. Jakarta: YT Leadership Foundation, 2003. Yesus Kristus Juruselamat Dunia. Jakarta: YT Leadership Foundation, 2004.

Webster, Noah. Webster's New Universal Dictionary of the English Language: Unabridge. Grand Rapids: Webster's universal Press, 1976.

Widjaja, Fransiskus Irwan, Candra Gunawan Marisi, T. Mangiring Tua Togatorop, and Handreas Hartono. "Menstimulasi Praktik Gereja Rumah Di Tengah Pandemi Covid- 
19.” Kurios (Jurnal Teologi dan Pendidikan Agama Kristen) 6, no. 1 (April 30, 2020):

127-139. Accessed September 30, 2020. http://www.sttpb.ac.id/ejournal/index.php/kurios.

Wisley, Tom N., and Charles H. Kraft, eds. Readings in Dynamic Indigeneity. Pasadena: William Carey Library, 1979.

Woga, Edmund. Dasar-Dasar Misiologi. Yogyakarta: Kanisius, 2002. 